\title{
Reaction between Peroxy and Alkoxy Radicals Can Form Stable Adducts
}

\section{lyer, Siddharth}

2019-05-02

lyer , S , Rissanen , M P \& Kurtén , T 2019 , ' Reaction between Peroxy and Alkoxy Radicals Can Form Stable Adducts ', Journal of Physical Chemistry Letters, vol. 10 , no. 9 , pp. 2051-2057 . https://doi.org/10.1021/acs.jpclett.9b00405

http://hdl.handle.net/10138/301871

https://doi.org/10.1021/acs.jpclett.9b00405

cc_by

publishedVersion

Downloaded from Helda, University of Helsinki institutional repository.

This is an electronic reprint of the original article.

This reprint may differ from the original in pagination and typographic detail.

Please cite the original version. 


\title{
Reaction between Peroxy and Alkoxy Radicals Can Form Stable Adducts
}

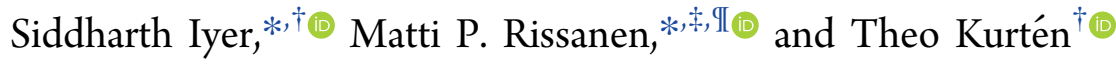 \\ ${ }^{\dagger}$ Department of Chemistry and Institute for Atmospheric and Earth System Research (INAR), University of Helsinki, P.O. Box 55, \\ FI-00014 Helsinki, Finland \\ ${ }^{\ddagger}$ Aerosol Physics Laboratory, Physics Unit, Tampere University, FI-33101 Tampere, Finland

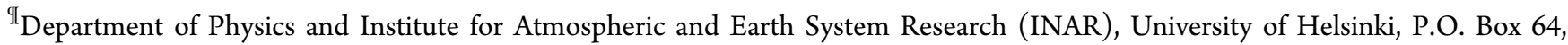 \\ FI-00014 Helsinki, Finland
}

\section{Supporting Information}

ABSTRACT: Peroxy $\left(\mathrm{RO}_{2}\right)$ and alkoxy $(\mathrm{RO})$ radicals are prototypical intermediates in any hydrocarbon oxidation. In this work, we use computational methods to (1) study the mechanism and kinetics of the $\mathrm{RO}_{2}+\mathrm{OH}$ reaction for previously unexplored " $\mathrm{R}$ " structures $(\mathrm{R}=$ $\mathrm{CH}(\mathrm{O}) \mathrm{CH}_{2}$ and $\mathrm{R}=\mathrm{CH}_{3} \mathrm{C}(\mathrm{O})$ ) and (2) investigate a hitherto unaccounted channel of molecular growth, $\mathrm{R}^{\prime} \mathrm{O}_{2}+\mathrm{RO}$. On the singlet surface, these reactions rapidly form $\mathrm{ROOOH}$ and $\mathrm{R}^{\prime} \mathrm{OOOR}$ adducts, respectively. The former decomposes to $\mathrm{RO}+\mathrm{HO}_{2}$ and $\mathrm{R}(\mathrm{O}) \mathrm{OH}+\mathrm{O}_{2}$ products, while the main decomposition channel for the latter is back to the reactant radicals. Decomposition rates of $\mathrm{R}^{\prime} \mathrm{OOOR}$ adducts varied between 103 and $0.015 \mathrm{~s}^{-1}$ at $298 \mathrm{~K}$ and $1 \mathrm{~atm}$. The most long-lived $\mathrm{R}^{\prime} \mathrm{OOOR}$ adducts likely account for some fraction of the elemental compositions detected in the atmosphere that are commonly assigned to

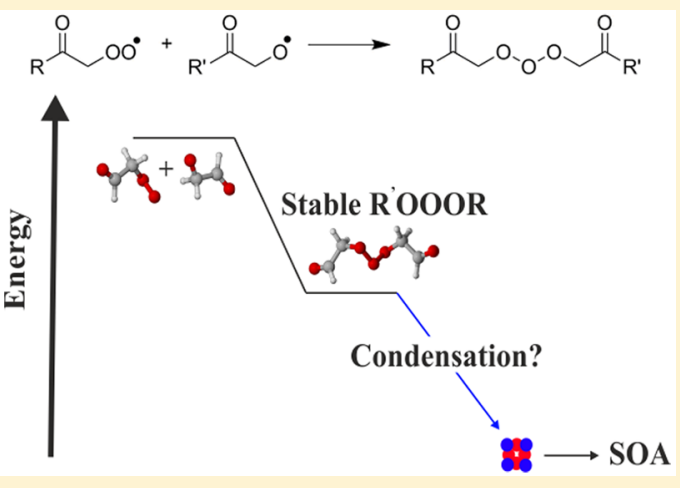
stable covalently bound dimers.

$\mathrm{O}$ rganic peroxy radicals $\left(\mathrm{RO}_{2}\right)$ produced from the oxidation of volatile organic compounds (VOCs) are known to play an important role in, for example, trace gas removal, generation of ozone, and the formation of secondary organic aerosol (SOA) in the atmosphere. ${ }^{1-4}$ An important sink pathway of $\mathrm{RO}_{2}$ in polluted environments is the reaction with $\mathrm{NO}$, which leads to the formation of $\mathrm{NO}_{2} . \mathrm{NO}_{2}$ subsequently photolyzes in the atmosphere and leads to the net formation of one ozone $\left(\mathrm{O}_{3}\right)$ molecule. In unpolluted areas, $\mathrm{RO}_{2}$ is mainly lost to reactions with the hydroperoxy radical $\left(\mathrm{HO}_{2}\right)$ and with other peroxy radicals. Unimolecular $\mathrm{H}$-shift isomerization reactions can outcompete these bimolecular reactions for certain $\mathrm{RO}_{2}{ }^{5,6}$ Alkoxy radicals ( $\mathrm{RO}$ ) are products of $\mathrm{RO}_{2}+\mathrm{RO}_{2}$ and $\mathrm{RO}_{2}+\mathrm{NO}$ reactions. An additional $\mathrm{RO}$ source is the photolysis of peroxides. ${ }^{7}$ Sink pathways of alkoxy radicals in the atmosphere include reaction with $\mathrm{O}_{2}$, leading to the formation of a carbonyl compound and $\mathrm{HO}_{2}$, isomerization via intramolecular hydrogen shifts, and decomposition via bond fission.

Recently, multiple theoretical and experimental studies have reported that the $\mathrm{RO}_{2}+\mathrm{OH}$ (hydroxy radical) reaction could be a significant sink channel for peroxy radicals under remote conditions, such as in the marine boundary layer. ${ }^{8-16}$ This reaction for methyl peroxy radical is reportedly quick, with a rate coefficient of $1.6 \times 10^{-10} \mathrm{~cm}^{3} \mathrm{~s}^{-1}$ at $295 \mathrm{~K}^{11}$ The fast reaction rate partially compensates for the relatively lower concentrations of $\mathrm{OH}$ compared to the $\mathrm{HO}_{2}$ radical, and the $\mathrm{RO}_{2}+\mathrm{OH}$ reaction may thus compete with the $\mathrm{RO}_{2}+\mathrm{HO}_{2}$ reaction whenever the
$\mathrm{HO}_{2} / \mathrm{OH}$ ratio is low. Studies on larger $\mathrm{C}_{2}$ to $\mathrm{C}_{4}$ alkyl peroxy radicals found the $\mathrm{RO}_{2}+\mathrm{OH}$ reaction rate coefficient to be 1.3$1.5 \times 10^{-10} \mathrm{~cm}^{3} \mathrm{~s}^{-1} .{ }^{17}$

Studies on $\mathrm{CH}_{3} \mathrm{O}_{2}+\mathrm{OH}^{13,14}$ and $\mathrm{C}_{2} \mathrm{H}_{5} \mathrm{O}_{2}+\mathrm{OH}^{15}$ show that these reactions proceed almost exclusively via the barrierless formation of a $\mathrm{ROOOH}$ trioxide intermediate on the singlet surface, with $\mathrm{RO}+\mathrm{HO}_{2}$ being the lowest-energy fragmentation channel. This is in agreement with the observed $80 \% \mathrm{HO}_{2}$ yield for the $\mathrm{CH}_{3} \mathrm{O}_{2}+\mathrm{OH}$ reaction. ${ }^{18}$ For peroxy radicals $\mathrm{CH}_{3} \mathrm{OO}$, $\mathrm{CH}_{3} \mathrm{CH}_{2} \mathrm{OO}, \mathrm{CH}_{3} \mathrm{CH}_{2} \mathrm{CH}_{2} \mathrm{OO}$, and $\mathrm{CH}_{3} \mathrm{CH}_{2} \mathrm{CH}_{2} \mathrm{CH}_{2} \mathrm{OO}$, the increase in the "R" size corresponded to a decrease in $\mathrm{HO}_{2}$ yield $(0.9,0.75,0.41$, and 0.15 , respectively) in the experimental study of the $\mathrm{RO}_{2}+\mathrm{OH}$ reaction reported by Assaf et $\mathrm{al}^{19}$ This points to more efficient stabilization of the larger $\mathrm{ROOOH}$ intermediates. Similar mechanistic studies for nonalkyl peroxy radical types have not been carried out. In this work, the kinetics of the $\mathrm{RO}_{2}+\mathrm{OH}$ reactions are inspected also for the carbonyl containing acetyl and $\beta$-oxo peroxy radicals. Differences in $\mathrm{RO}_{2}$ structures have previously been observed to significantly alter product branching ratios. Hasson et al., ${ }^{20}$ for example, reported a strong structure dependence for the different product channels of the $\mathrm{RO}_{2}+\mathrm{HO}_{2}$ reaction, where " $\mathrm{R}$ " is either an alkyl, acetonyl, or acetyl group.

Received: February 12, 2019

Accepted: April 8, 2019

Published: April 8, 2019 
a)

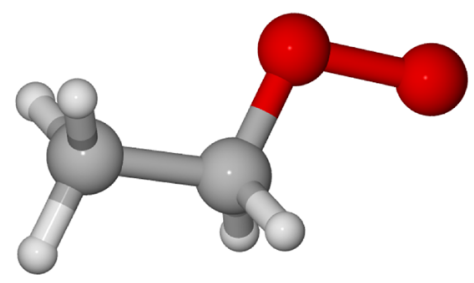

b)

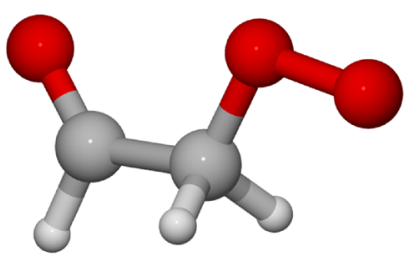

c)

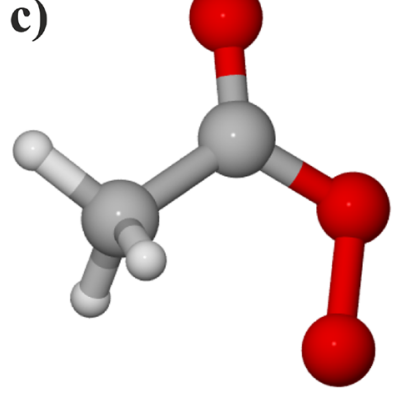

Figure 1. (a) $\mathrm{CH}_{3} \mathrm{CH}_{2} \mathrm{OO}$, (b) $\mathrm{CH}(\mathrm{O}) \mathrm{CH}_{2} \mathrm{OO}$, and (c) $\mathrm{CH}_{3} \mathrm{C}(\mathrm{O}) \mathrm{OO}$ peroxy radicals.

Like $\mathrm{RO}_{2}$ and $\mathrm{HO}_{2}, \mathrm{RO}$ and $\mathrm{OH}$ often have similar or analogous reactivities, and one can postulate that the $\mathrm{R}^{\prime} \mathrm{O}_{2}+\mathrm{RO}$ reaction should go through a similar trioxide adduct $\left(\mathrm{R}^{\prime} \mathrm{OOOR}\right.$ in this case) as the $\mathrm{RO}_{2}+\mathrm{OH}$ reaction. The atmospheric importance of the $\mathrm{R}^{\prime} \mathrm{O}_{2}+\mathrm{RO}$ reaction depends on the steadystate $\mathrm{RO}$ concentration, which is generally assumed to be small due to the high loss rates of alkoxy radicals. Considering an effective RO loss rate between $1 \times 10^{6}$ and $1 \times 10^{3} \mathrm{~s}^{-1}$, together with atmospherically representative values for the RO source terms, we obtain an ambient $\mathrm{RO}$ concentration range from 2 to 1 $\times 10^{5}$ molecules $\mathrm{cm}^{-3}$ (see section $\mathrm{S} 6$ for details). If the formation of the $\mathrm{R}^{\prime} \mathrm{OOOR}$ adducts is fast and they are sufficiently stable, they could thus constitute a fraction of the low-volatility organic compounds in the atmosphere referred to as dimers. ${ }^{1,21,22}$ Recently, $\mathrm{R}^{\prime} \mathrm{OOOR}$ formed via a $\mathrm{R}^{\prime} \mathrm{O}_{2}+\mathrm{RO}$ reaction was tentatively suggested ${ }^{23}$ as the mechanism involved in the formation of $\mathrm{C}_{19} \mathrm{H}_{28} \mathrm{O}_{11}$, a major dimer peak reported in multiple nitrate chemical ionization mass spectrometry-based laboratory and ambient studies of $\alpha$-pinene ozonolysis. ${ }^{1,24-27}$

Additionally, the $\mathrm{R}^{\prime} \mathrm{O}_{2}+\mathrm{RO}$ reaction along the triplet surface could potentially lead to low barrier product channels, forming, for example, Criegee intermediates $\left(\mathrm{CI}\right.$; denoted by $\mathrm{R}_{-\mathrm{H}}^{\prime} \mathrm{OO}^{\bullet}$ in reaction 2) that play a critical role in the oxidative capacity of the atmosphere and in SOA formation. ${ }^{28-31}$ The possible reaction channels of $\mathrm{R}^{\prime} \mathrm{O}_{2}+\mathrm{RO}$ are

$$
\begin{aligned}
& \mathrm{R}^{\prime} \mathrm{O}_{2}+\mathrm{RO} \rightleftharpoons \mathrm{R}^{\prime} \mathrm{OOOR} \\
& \mathrm{R}^{\prime} \mathrm{OOOR} \rightarrow \mathrm{R}_{-\mathrm{H}}^{\prime \bullet} \mathrm{OO}+\mathrm{ROH} \\
& \mathrm{R}^{\prime} \mathrm{OOOR} \rightarrow \mathrm{R}_{-\mathrm{H}}^{\prime}=\mathrm{O}+\mathrm{ROOH} \\
& \mathrm{R}^{\prime} \mathrm{OOOR} \rightarrow \mathrm{RO}_{2}+\mathrm{R}^{\prime} \mathrm{O}
\end{aligned}
$$

We considered 2-carbon $\mathrm{CH}_{3} \mathrm{CH}_{2} \mathrm{OO}, \mathrm{CH}(\mathrm{O}) \mathrm{CH}_{2} \mathrm{OO}$, and $\mathrm{CH}_{3} \mathrm{C}(\mathrm{O}) \mathrm{OO}$ peroxy/alkoxy radicals (see Figure 1 for the $\mathrm{RO}_{2}$ systems; the RO systems were identical except for an oxy radical group instead of a peroxy radical group). For the $\mathrm{RO}_{2}+\mathrm{OH}$ reaction, only $\mathrm{CH}(\mathrm{O}) \mathrm{CH}_{2} \mathrm{OO}$ and $\mathrm{CH}_{3} \mathrm{C}(\mathrm{O}) \mathrm{OO}$ systems were studied here as $\mathrm{CH}_{3} \mathrm{CH}_{2} \mathrm{OO}$ has already been investigated in detail previously. ${ }^{15}$

On the singlet surface, the decomposition of the $\beta$-oxo $\mathrm{CH}(\mathrm{O}) \mathrm{CH}_{2} \mathrm{OOOH}$ adduct primarily follows the $\mathrm{CH}(\mathrm{O}) \mathrm{CH}_{2} \mathrm{O}$ $+\mathrm{HO}_{2}$ channel (see section $\mathrm{S} 1$ for details), which is analogous to the previously studied alkyl $\mathrm{CH}_{3} \mathrm{CH}_{2} \mathrm{OOOH} .{ }^{15,18,19}$ However, the acetyl $\mathrm{CH}_{3} \mathrm{C}(\mathrm{O}) \mathrm{OOOH}$ adduct will rather decompose into $\mathrm{CH}_{3} \mathrm{C}(\mathrm{O}) \mathrm{OH}+{ }^{1} \mathrm{O}_{2}$ as this channel has a low barrier. Total firstorder decomposition rates of $\mathrm{CH}(\mathrm{O}) \mathrm{CH}_{2} \mathrm{OOOH}$ and $\mathrm{CH}_{3} \mathrm{C}$ (O) $\mathrm{OOOH}$ adducts were calculated using the master equation solver for multienergy well reactions (MESMER) program and were found to be $2.7 \times 10^{-3}$ and $1.9 \times 10^{3} \mathrm{~s}^{-1}$, respectively.
Formation of the adducts is unfavorable on the triplet surface for both sets of reactions (see Figure S5). The reaction stationary points with the energies of the different breakup channels on the singlet and triplet surfaces and the MESMER-simulated pressure and temperature dependencies of the $\mathrm{ROOOH}$ formation rate coefficients are provided in section $\mathrm{S} 1$.

Similarly to the $\mathrm{RO}_{2}+\mathrm{OH}$ reaction, $\mathrm{R}^{\prime} \mathrm{O}_{2}+\mathrm{RO}$ also forms a trioxide adduct ( $\mathrm{R}^{\prime} \mathrm{OOOR}$, in this case) on the singlet surface for the studied systems. A relaxed scan over the $\mathrm{R}^{\prime} \mathrm{OO} \cdots \mathrm{OR}$ bond showed that this reaction is barrierless, at least at the $\omega \mathrm{B} 97 \mathrm{X}-\mathrm{D} /$ $6-31+G(d)$ level of theory (see section S8 for details). The adduct can then decompose in four ways, illustrated in reactions 1 (back to parent reactants), 2, 3, and 4 (the possible product channels). Figure 2 shows the stationary points of the $\mathrm{R}^{\prime} \mathrm{O}_{2}+$ $\mathrm{RO}$ reaction on the singlet surface. The reactants can also form a $\mathrm{CI}$ and an alcohol directly. However, this reaction has a barrier of $\sim 2 \mathrm{kcal} / \mathrm{mol}$ and higher in zero-point-corrected energy $(\sim 12$ $\mathrm{kcal} / \mathrm{mol}$ in free energy) for the studied systems and is therefore unlikely to compete with the formation of the R'OOOR adduct. Details of this reaction are provided in section S2. We note that $\mathrm{CH}(\mathrm{O}) \mathrm{CH}_{2} \mathrm{OO}$ will undergo a fast 1,4-aldehydic $\mathrm{H}$-shift ${ }^{6}$ and that the decomposition of the $\mathrm{CH}_{3} \mathrm{C}(\mathrm{O}) \mathrm{O}$ acetyloxy radical to form $\mathrm{CH}_{3}$ and $\mathrm{CO}_{2}$ has a very small barrier. ${ }^{7}$ Especially the $\mathrm{CH}_{3} \mathrm{C}(\mathrm{O}) \mathrm{O}$ radical will therefore not live long enough to undergo bimolecular reactions in the atmosphere. The two systems are nevertheless included here for completeness and to demonstrate the effect of reactant structure on the product channels. Other $\beta$-oxo peroxy and acetyloxy radicals could have longer lifetimes, and their participation in bimolecular reactions cannot be ruled out.

The $\mathrm{R}^{\prime} \mathrm{OOO}$ adducts are significantly lower in energy relative to the reactants on the singlet surface. Considering the high reactivity of $\mathrm{RO}$ radicals and that the reaction was found to be barrierless, the formation of the $\mathrm{R}^{\prime} \mathrm{OOOR}$ adduct is likely facile for all atmospherically relevant $\mathrm{RO}+\mathrm{RO}_{2}$ combinations. While the decomposition channels of the ROOOH adduct had barriers that were mostly below the reactant energies (and therefore more likely to be competitive; see Figure S1), the transition state energies connecting the two breakup channels of $\mathrm{R}^{\prime}$ OOOR illustrated in reactions 2 and 3 were above the reactant energy for all cases (except for the $\beta$-oxo-acetyl case, which had a barrier of $-0.5 \mathrm{kcal} / \mathrm{mol}$ relative to the reactants for reaction 2 ; see Figure $2 \mathrm{~b}$ ). The barrier heights for reactions 2 and 3 are $\sim 23-32$ and $\sim 33-37 \mathrm{kcal} / \mathrm{mol}$ above the $\mathrm{R}^{\prime} \mathrm{OOOR}$ intermediate, respectively, for all studied systems. These are therefore not competitive with decomposition back into $\mathrm{R}^{\prime} \mathrm{O}_{2}+$ $\mathrm{RO}$ (or $\mathrm{R}^{\prime} \mathrm{O}+\mathrm{RO}_{2}$ ). The Criegee-forming channel via the trioxide intermediate (reaction 2) was found to have a relatively low barrier $(23-24 \mathrm{kcal} / \mathrm{mol}$ relative to the trioxide 
a)

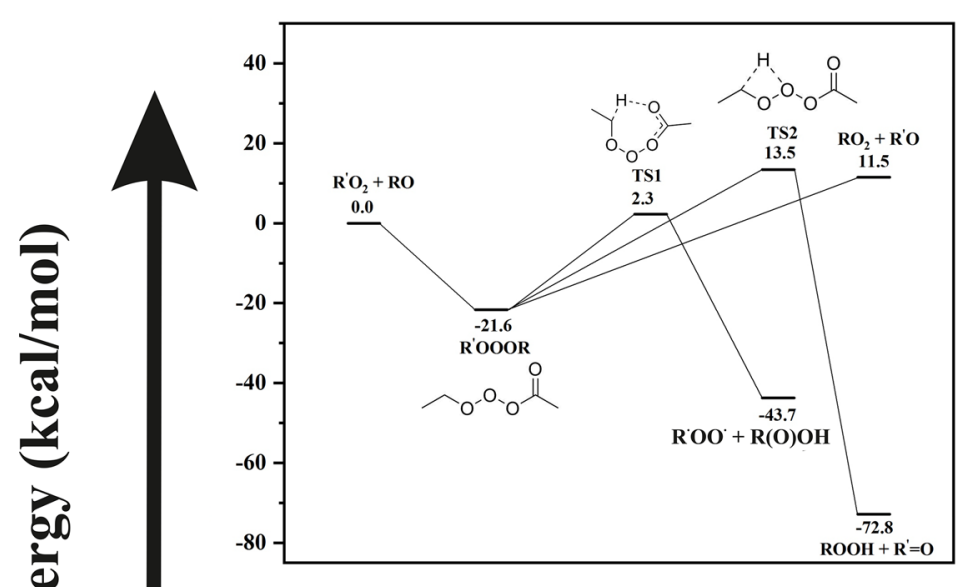

c)

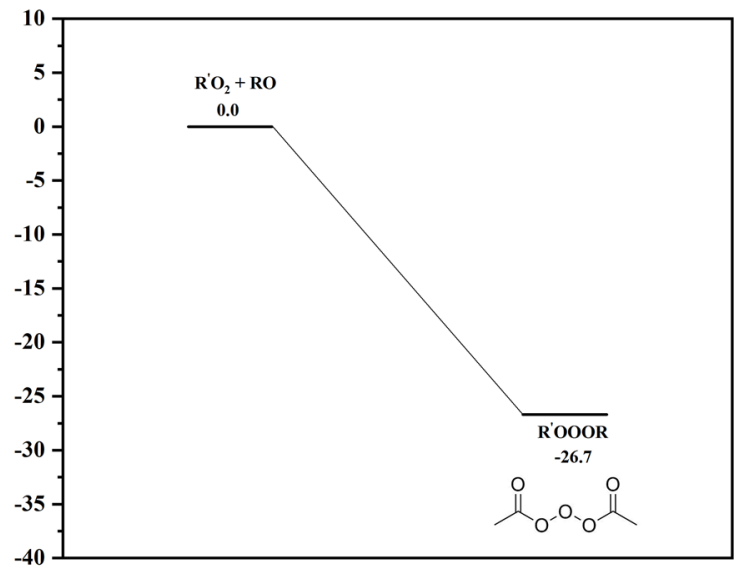

e)

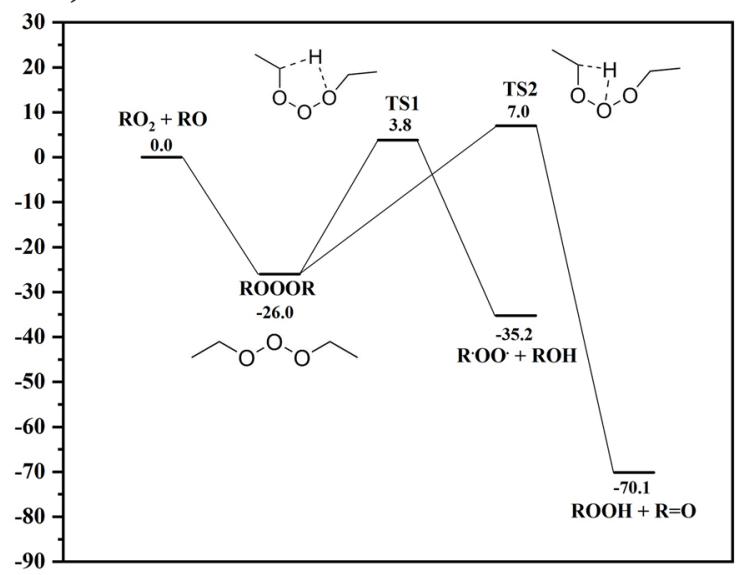

b)

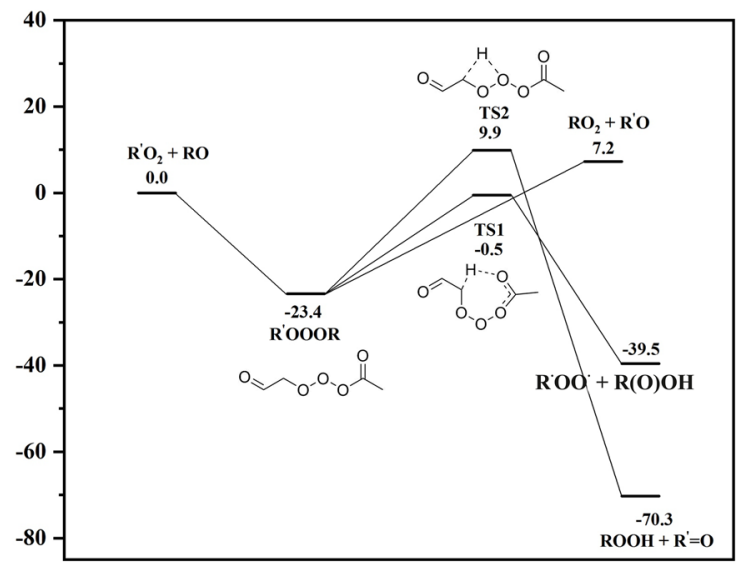

d)

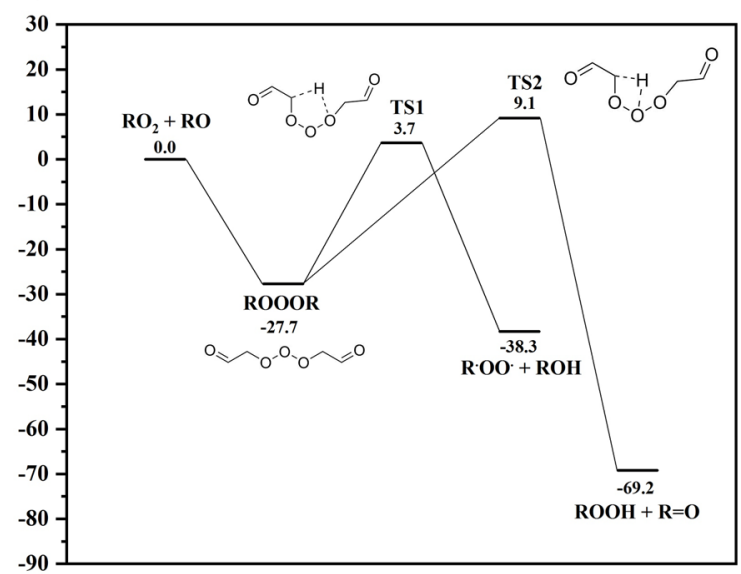

f)

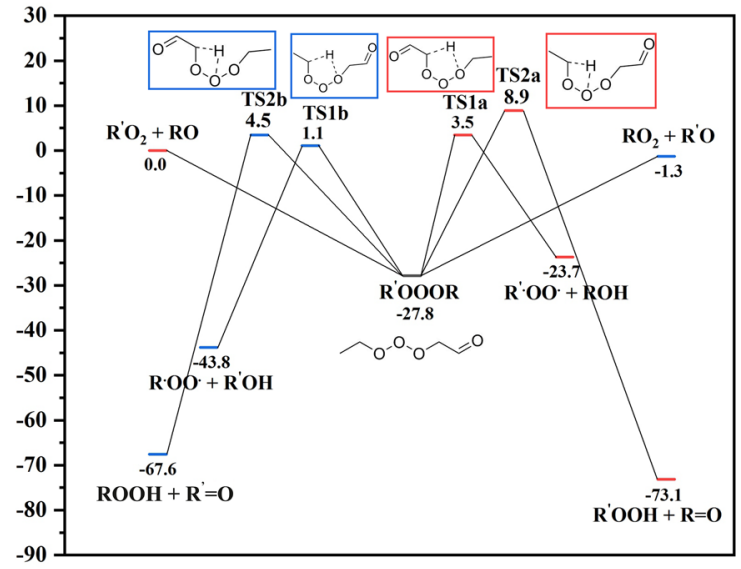

\section{Reaction coordinate}

Figure 2. Stationary points on the singlet surface of the reaction $\mathrm{R}^{\prime} \mathrm{O}_{2}+\mathrm{RO}$ for $(\mathrm{a})$ acetyl $(\mathrm{R})+$ alkyl $\left(\mathrm{R}^{\prime}\right),(\mathrm{b})$ acetyl $(\mathrm{R})+\beta$-oxo $\left(\mathrm{R}^{\prime}\right)$, (c) acetyl $(\mathrm{R})+$ $\operatorname{acetyl}\left(\mathrm{R}^{\prime}\right),(\mathrm{d}) \beta$-oxo $(\mathrm{R})+\beta$-oxo $\left(\mathrm{R}^{\prime}\right),(\mathrm{e})$ alkyl $(\mathrm{R})+\operatorname{alkyl}\left(\mathrm{R}^{\prime}\right)$, and $(\mathrm{f})$ alkyl $(\mathrm{R})+\beta$-oxo $\left(\mathrm{R}^{\prime}\right)$ systems calculated at the $\mathrm{ROHF}-\mathrm{RCCSD}(\mathrm{T})$ - $\mathrm{F} 12 \mathrm{a} /$ VDZ-F12// $\omega$ B97X-D/aug-cc-pVTZ level.

intermediate) for the acetyl- $\beta$-oxo and acetyl-alkyl systems. This is due to the added flexibility afforded by the carbonyl oxygen of the acetyl molecule to the H-shift transition state geometry (see Figure S8). The transition state corresponding to reaction 3 requires contortion of the trioxide group, and the barrier involved is significantly higher.

The MESMER-simulated total first-order R'OOOR loss rate coefficients and the likely decomposition channels are shown in 
Table 1. MESMER-Derived Total First-Order Bartis-Widom Phenomenological Loss Rate Coefficients $\left(k_{\mathrm{m}}\right)$ of $\mathrm{R}^{\prime}$ OOOR at 298 $\mathrm{K}$ and $1 \mathrm{~atm}$ Bath Gas $\left(\mathrm{N}_{2}\right)$ Pressure

\begin{tabular}{|c|c|c|c|c|}
\hline & $\mathrm{RO}_{2}+\mathrm{RO}$ type & $\mathrm{R}^{\prime}$ OOOR Structure & Likely breakup pathway & $\mathrm{k}_{m}\left(\mathrm{~s}^{-1}\right)$ \\
\hline a & $\mathrm{CH}_{3} \mathrm{C}(\mathrm{O}) \mathrm{OO}+\mathrm{CH}_{3} \mathrm{CH}_{2} \mathrm{O}$ & & $\mathrm{CH}_{3} \mathrm{CH}_{2} \mathrm{OO}+\mathrm{CH}_{3} \mathrm{C}(\mathrm{O}) \mathrm{O}$ & 102.6 \\
\hline b & $\mathrm{CH}_{3} \mathrm{C}(\mathrm{O}) \mathrm{OO}+\mathrm{CH}(\mathrm{O}) \mathrm{CH}_{2} \mathrm{O}$ & & $\mathrm{CH}(\mathrm{O}) \mathrm{CH}_{2} \mathrm{OO}+\mathrm{CH}_{3} \mathrm{C}(\mathrm{O}) \mathrm{O}$ & 47.7 \\
\hline c & $\mathrm{CH}_{3} \mathrm{C}(\mathrm{O}) \mathrm{OO}+\mathrm{CH}_{3} \mathrm{C}(\mathrm{O}) \mathrm{O}$ & & $\mathrm{CH}_{3} \mathrm{C}(\mathrm{O}) \mathrm{OO}+\mathrm{CH}_{3} \mathrm{C}(\mathrm{O}) \mathrm{O}$ & $5.1 \times 10^{-2}$ \\
\hline d & $\mathrm{CH}(\mathrm{O}) \mathrm{CH}_{2} \mathrm{OO}+\mathrm{CH}(\mathrm{O}) \mathrm{CH}_{2} \mathrm{O}$ & $\mathrm{O}=\mathrm{O}_{0} \mathrm{O} \sim \mathrm{O}$ & $\mathrm{CH}(\mathrm{O}) \mathrm{CH}_{2} \mathrm{OO}+\mathrm{CH}(\mathrm{O}) \mathrm{CH}_{2} \mathrm{O}$ & $1.5 \times 10^{-2}$ \\
\hline e & $\mathrm{CH}_{3} \mathrm{CH}_{2} \mathrm{OO}+\mathrm{CH}_{3} \mathrm{CH}_{2} \mathrm{O}$ & & $\mathrm{CH}_{3} \mathrm{CH}_{2} \mathrm{OO}+\mathrm{CH}_{3} \mathrm{CH}_{2} \mathrm{O}$ & $2.0 \times 10^{-1}$ \\
\hline f & $\mathrm{CH}(\mathrm{O}) \mathrm{CH}_{2} \mathrm{OO}+\mathrm{CH}_{3} \mathrm{CH}_{2} \mathrm{O}$ & $\widehat{八}_{0}-0$ & $\mathrm{CH}_{3} \mathrm{CH}_{2} \mathrm{OO}+\mathrm{CH}(\mathrm{O}) \mathrm{CH}_{2} \mathrm{O}$ & $1.7 \times 10^{-2}$ \\
\hline
\end{tabular}

a)

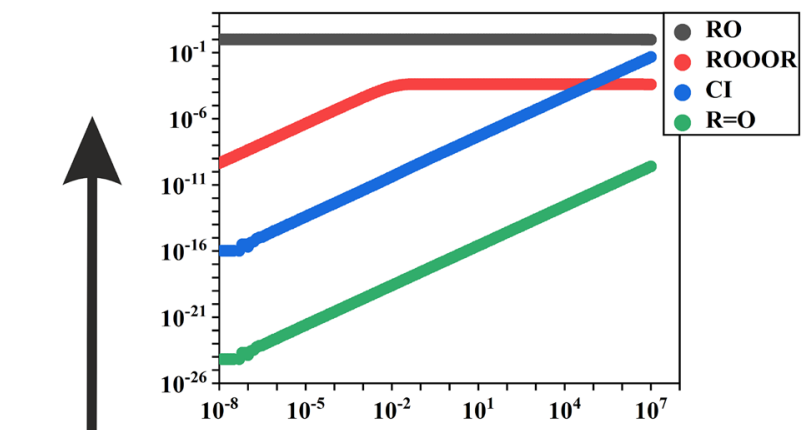

c)

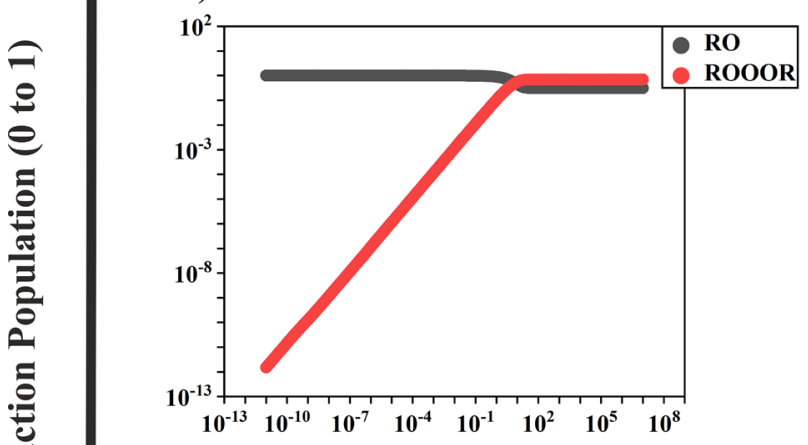

e)

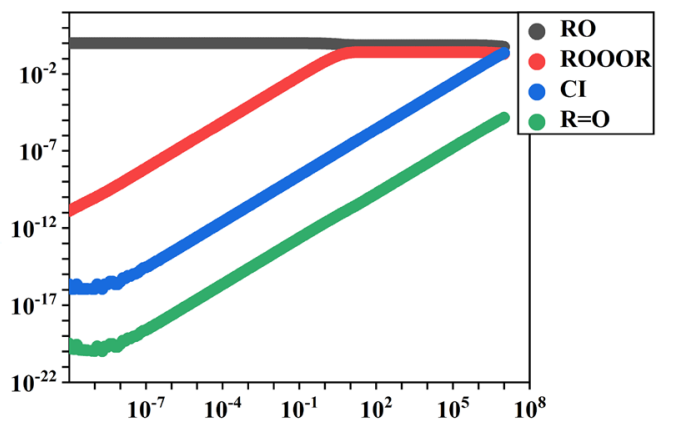

b)

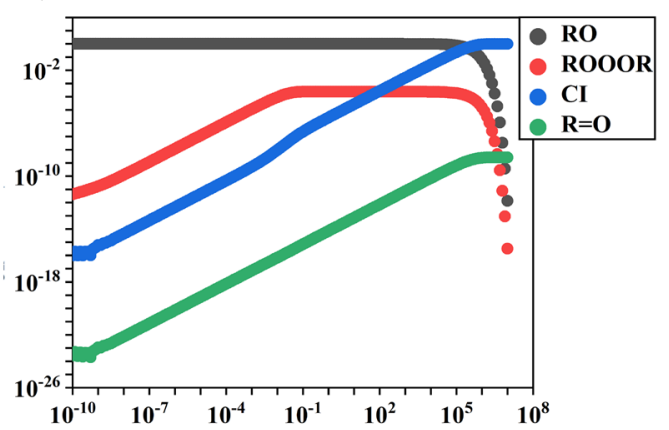

d)

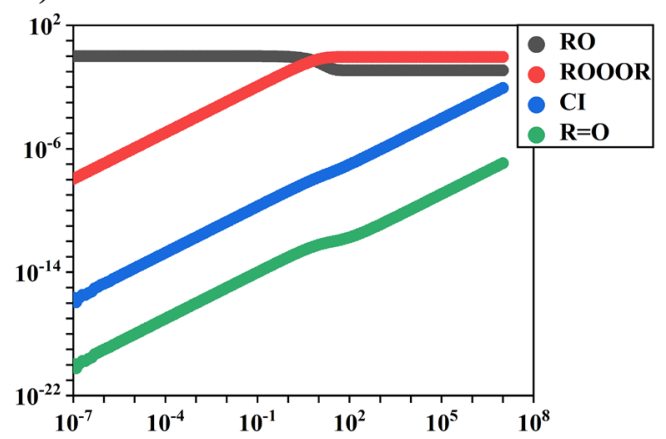

f)

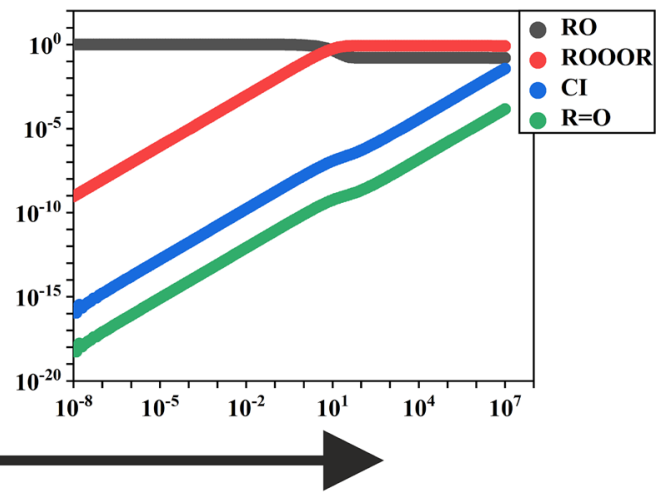

Time (s)

Figure 3. MESMER-simulated species profiles of reactant $\mathrm{RO}$, intermediate $\mathrm{R}^{\prime} \mathrm{OOOR}$, and possible products $\left.\mathrm{CI}\left(\mathrm{R}_{-\mathrm{H}}^{\prime} \mathrm{OO}\right)^{\bullet}\right)$ and $\mathrm{R}=\mathrm{O}$ for $(\mathrm{a})$ acetyl $(\mathrm{R})+\operatorname{alkyl}\left(\mathrm{R}^{\prime}\right),(\mathrm{b}) \operatorname{acetyl}(\mathrm{R})+\beta$-oxo $\left(\mathrm{R}^{\prime}\right),(\mathrm{c}) \operatorname{acetyl}(\mathrm{R})+\operatorname{acetyl}\left(\mathrm{R}^{\prime}\right),(\mathrm{d}) \beta$-oxo $(\mathrm{R})+\beta$-oxo $\left(\mathrm{R}^{\prime}\right),(\mathrm{e})$ alkyl $(\mathrm{R})+\operatorname{alkyl}\left(\mathrm{R}^{\prime}\right)$, and $(\mathrm{f})$ alkyl $(\mathrm{R})+\beta$ oxo $\left(\mathrm{R}^{\prime}\right)$ systems calculated at $298 \mathrm{~K}, 1$ atm bath gas $\left(\mathrm{N}_{2}\right)$ pressure, and an $\mathrm{RO}_{2}$ concentration of $1 \times 10^{9}$ molecules $\mathrm{cm}^{-3}$.

Table 1, and species concentration profiles of reactant RO, intermediate $\mathrm{R}^{\prime} \mathrm{OOOR}$, and the possible products $\mathrm{CI}$ $\left(\mathrm{R}_{-\mathrm{H}}^{\prime} \mathrm{OO}{ }^{\bullet}\right)$ and $\mathrm{R}=\mathrm{O}$ are shown in Figure $3 . \mathrm{RO}_{2}$ was assigned as the excess reactant and given a value of $1 \times 10^{9}$ molecules $\mathrm{cm}^{-3}$ in the simulations as this was calculated to be a roughly representative steady-state peroxy radical concentration in both pristine and polluted conditions (see section S6 for details). Figure 4 shows the first-order $\mathrm{R}^{\prime} \mathrm{OOOR}$ decomposition rate coefficients via the different possible channels. The pressureand temperature-dependent formation rate coefficient of the 


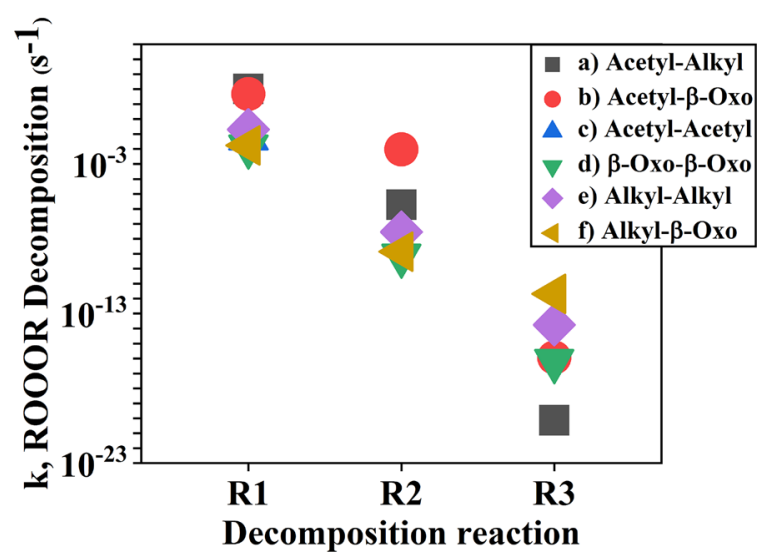

Figure 4. MESMER-simulated $\mathrm{R}^{\prime} \mathrm{OOOR}$ decomposition rate coefficients via the different possible product channels for the studied systems calculated at $298 \mathrm{~K}$ temperature and 1 atm pressure. R1: $\mathrm{R}^{\prime} \mathrm{OOOR} \rightarrow \mathrm{R}^{\prime} \mathrm{O}_{2}+\mathrm{RO}$; R2: $\mathrm{R}^{\prime} \mathrm{OOOR} \rightarrow \mathrm{R}_{-\mathrm{H}}^{\prime} \mathrm{OO}^{\bullet}+\mathrm{ROH}$; R3: $\mathrm{R}^{\prime} \mathrm{OOOR} \rightarrow \mathrm{R}^{\prime} \mathrm{OOH}+\mathrm{R}=\mathrm{O}$.

$\mathrm{R}^{\prime}$ OOOR intermediate for the $\mathrm{CH}(\mathrm{O}) \mathrm{CH}_{2} \mathrm{OO}+\mathrm{CH}(\mathrm{O})$ $\mathrm{CH}_{2} \mathrm{O}$ system is shown in Figure 5. Similar plots for the

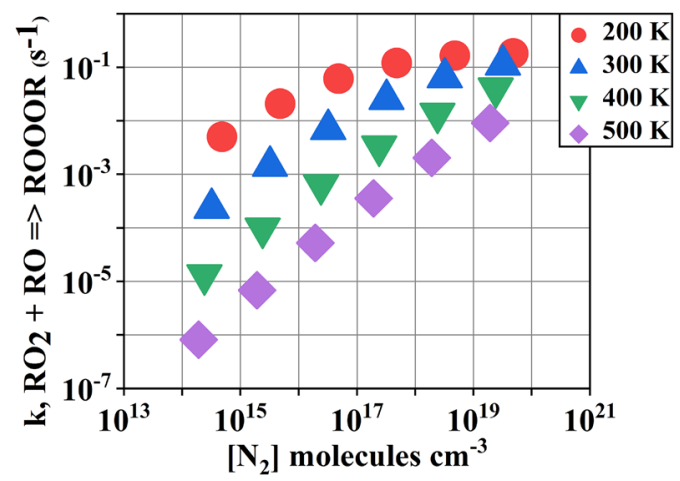

Figure 5. MESMER-simulated temperature and pressure dependence of the $\mathrm{R}^{\prime} \mathrm{OOOR}$ formation rate coefficients for the $\mathrm{CH}(\mathrm{O}) \mathrm{CH}_{2} \mathrm{OO}+$ $\mathrm{CH}(\mathrm{O}) \mathrm{CH}_{2} \mathrm{O}$ system. Pseudounimolecular rate coefficient in units of $\mathrm{s}^{-1}$ were calculated for a $\mathrm{RO}_{2}$ concentration of $1 \times 10^{9}$ molecules $\mathrm{cm}^{-3}$.

remaining studied systems are provided in section S2. The stationary points on the triplet surface for the studied systems are shown in section S5. Analogous to $\mathrm{ROOOH}$, the formation of $\mathrm{R}^{\prime} \mathrm{OOOR}$ adducts was found to be highly unfavorable on the triplet surface.

Of the studied cases, the fastest $\mathrm{R}^{\prime} \mathrm{OOOR}$ decomposition rates corresponded to systems where one of the reacting radicals is of the acetyl type and the other is of either an alkyl or $\beta$-oxo type (see Table 1). In these cases, the stability of the R'OOOR intermediate is relatively low, leading to rapid decomposition back into $\mathrm{R}^{\prime} \mathrm{O}_{2}+\mathrm{RO}$ (or $\mathrm{R}^{\prime} \mathrm{O}+\mathrm{RO}_{2}$ ) (see Figure $2 \mathrm{a}$, b and Table $1)$. This is likely due to the resonance stabilization of the acetyloxy radical, which lowers the energy of this product channel. When both reactant radicals are of the acetyl type, the only decomposition channel possible for the $\mathrm{R}^{\prime} \mathrm{OOOR}$ intermediate is back into the parent reactants (shown in Figure 2c) as the acetyl $\mathrm{RO}_{2}$ can form neither a CI nor an aldehyde (due to the lack of $\mathrm{H}$-atoms on the carbon atom containing the radical group). Note that $\mathrm{CH}_{3} \mathrm{C}(\mathrm{O}) \mathrm{OO}+\mathrm{CH}_{3} \mathrm{C}(\mathrm{O}) \mathrm{O}$ will never occur in the atmosphere as the barrier for the decomposition of this acetyloxy radical into $\mathrm{CH}_{3}$ and $\mathrm{CO}_{2}$ has a barrier of only about $\sim 3 \mathrm{kcal} / \mathrm{mol}$ in zero-point corrected energies. ${ }^{7}$ The $\mathrm{R}^{\prime} \mathrm{OOOR}$ formed from the homo and hetero alkyl/ $\beta$-oxo systems (see Figure $2 \mathrm{~d}-\mathrm{f}$ ) is significantly more stable, and the rate of decomposition back to $\mathrm{R}^{\prime} \mathrm{O}_{2}+\mathrm{RO}$ (or $\mathrm{R}^{\prime} \mathrm{O}+\mathrm{RO}_{2}$ ) is accordingly slower (see Table 1 ). The most stable $\mathrm{R}^{\prime} \mathrm{OOOR}$ intermediate was found for the $\beta$-oxo- $\beta$-oxo system, which has a decomposition rate (at $298 \mathrm{~K}$ and $1 \mathrm{~atm}$ ) of $1.5 \times 10^{-2} \mathrm{~s}^{-1}$. The stability of $\mathrm{R}^{\prime} \mathrm{OOOR}$ adducts is thus in line with that of the analogous species $R^{\prime} O O R$ and $R^{\prime} O O O O R$. While reactive, the former can have room-temperature lifetimes on the order of weeks or more, whereas the latter have been postulated since 1957 to be intermediates of $\mathrm{RO}_{2}+\mathrm{RO}_{2}$ reactions but have such short lifetimes that they have, to our knowledge, never been experimentally detected. ${ }^{32,33}$

On the triplet surface, the $\mathrm{R}^{\prime} \mathrm{O}_{2}+\mathrm{RO}$ product channels have significant barriers (see section S5). Similarly to the $\mathrm{RO}_{2}+\mathrm{OH}$ reaction (section $\mathrm{S} 1$ ), reactions on the triplet surface would need to be essentially barrierless to be competitive with the rapid formation of the trioxide intermediates on the singlet surface. Given the calculated barrier heights reported here (several kcal/ $\mathrm{mol}$ in zero-point corrected energy and over $10 \mathrm{kcal} / \mathrm{mol}$ in free energy), none of the studied product channels on the triplet surface are likely competitive.

Our results indicate that the $\mathrm{R}^{\prime} \mathrm{O}_{2}+\mathrm{RO}$ reaction is a source of stable $\mathrm{R}^{\prime} \mathrm{OOOR}$ adducts. We estimated that the ambient steadystate concentrations of the adducts can range from 30 to $3 \times 10^{4}$ molecules $\mathrm{cm}^{-3}$ (see Table S5). Their stability was found to be strongly dependent on the structure of the reacting radicals that were considered, with decomposition rates ranging from a high of $\sim 50-100 \mathrm{~s}^{-1}$ for acetyl-alkyl and acetyl- $\beta$-oxo systems, respectively, and a low of $\sim 0.2-0.02 \mathrm{~s}^{-1}$ for the others. The binding energies (relative to $\mathrm{R}^{\prime} \mathrm{O}+\mathrm{RO}_{2}$ and $\mathrm{RO}+\mathrm{R}^{\prime} \mathrm{O}_{2}$ ) of $\mathrm{R}^{\prime} \mathrm{OOOR}$ adducts were computed at the $\omega \mathrm{B} 97 \mathrm{X}-\mathrm{D} / 6-31+\mathrm{G}(\mathrm{d})$ level for a series of larger (4-10 C-atoms) $\mathrm{RO}$ and $\mathrm{RO}_{2}$ generated in the oxidation of representative anthropogenic and biogenic VOC molecules (see section S7). The computed $\mathrm{R}^{\prime}$ OOOR stabilities were similar to those for the systems studied here (recomputed at the same level), indicating that the lifetimes of larger R'OOOR are also likely to be on the order of 10-100 s, in some cases (e.g., cyclohexene ozonolysis) possibly even higher. These stabilized adducts could therefore constitute a fraction of the low-volatile dimer compositions reported in ambient mass spectrometry measurements and are consequently important in SOA formation.

\section{METHODS}

Quantum Chemical Calculations. To calculate the stationary points of the studied reactions, a systematic conformer search was performed for each system using MMFF $^{34-39}$ implemented in the Spartan '14 program. ${ }^{40}$ For the reactant and product systems in the $\mathrm{RO}_{2}+\mathrm{OH}$ reaction, all conformers were optimized directly using density functional theory (DFT) at the $\omega$ B97X-D/aug-cc-pVTZ ${ }^{41-43}$ level due to the limited number of available conformers. For the $\mathrm{R}^{\prime} \mathrm{OOOR}$ intermediate complexes of the $\mathrm{R}^{\prime} \mathrm{O}_{2}+\mathrm{RO}$ reaction, however, the conformers were first optimized at the lower DFT B3LYP/6-31+G(d) level, ${ }^{44-48}$ and those within $2 \mathrm{kcal} / \mathrm{mol}$ in relative electronic energies were selected for the higher-level optimization at the $\omega \mathrm{B} 97 \mathrm{X}-\mathrm{D} / \mathrm{aug}$ cc-pVTZ level with the ultrafine integration grid. The transition state geometries connecting the different product channels studied here were found by performing a relaxed scan over the bond lengths of the appropriate atoms at the B3LYP/6$31+G(d)$ level of theory. The initial transition state optimization, as well as the intrinsic reaction coordinate 
(IRC) calculations to confirm that the transition states connected to the correct product channels, were performed at the same level. The transition states were subsequently reoptimized at the $\omega \mathrm{B} 97 \mathrm{X}-\mathrm{D} /$ aug-cc-pVTZ level of theory. The electronic energies of the lowest-energy conformers of all reactants, intermediates, transition states, and products were corrected using ROHF-RCCSD(T)-F12a/VDZ-F12 singlepoint energies calculated with the Molpro program. ${ }^{49}$ We note that the ROHF-RCCSD(T)-F12a/VDZ-F12 correction to the formation energies of $\mathrm{ROOOH}$ and $\mathrm{R}^{\prime} \mathrm{OOOR}$ adducts were significant, making their formation more exergonic by $\sim 4$ and $\sim 7-8 \mathrm{kcal} / \mathrm{mol}$, respectively, relative to pure DFT energies.

RRKM Calculations. The master equation solver for multienergy well reactions (MESMER) program $^{50}$ was used to calculate the Bartis-Widom ${ }^{51}$ phenomenological rate coefficients of the decomposition of the $\mathrm{ROOOH}$ and ROOOR intermediate complexes for the $\mathrm{RO}_{2}+\mathrm{OH}$ and $\mathrm{RO}_{2}+\mathrm{RO}$ reactions, respectively. Details of the MESMER program have been provided in detail by other authors in previous publications. ${ }^{52-55}$ MESMER uses the quantum chemically calculated zero-point corrected electronic energies, vibrational frequencies, and rotational constants. In addition, the program also requires the Lennard-Jones coefficients of the intermediate complex (ROOOH and $\mathrm{R}^{\prime} \mathrm{OOOR}$ ) and the bath gas $\left(\mathrm{N}_{2}\right)$ and the exponential down energy transfer parameter, $\Delta E_{\text {down }}$, for the collisional energy transfer model for $\mathrm{N}_{2}$. Details of the MESMER simulations, conditions, and parameters used are provided in section S3.

\section{ASSOCIATED CONTENT}

\section{S Supporting Information}

The Supporting Information is available free of charge on the ACS Publications website at DOI: 10.1021/acs.jpclett.9b00405.

Full computational details, log files of optimized reactants, intermediates, transition states and products containing the structures, energetics, vibrational frequencies, and rotational constants used in plotting the stationary points and running the MESMER simulations, details of the parameters used in MESMER simulations, pressure and temperature dependencies of formation rates of $\mathrm{ROOOH}$ and ROOOR intermediates and an example MESMER input file (PDF)

Molpro log and out files containing the ROHF-RCCSD(T)-F12a/VDZ-F12 single-point electronic energies (ZIP)

\section{AUTHOR INFORMATION}

\section{Corresponding Authors}

*E-mail: siddharth.iyer@helsinki.fi.

*E-mail: matti.rissanen@tuni.fi.

\section{ORCID $\odot$}

Siddharth Iyer: 0000-0001-5989-609X

Matti P. Rissanen: 0000-0003-0463-8098

Theo Kurtén: 0000-0002-6416-4931

Notes

The authors declare no competing financial interest.

\section{ACKNOWLEDGMENTS}

The authors thank the Academy of Finland (266388,299574) for funding and the CSC IT Center for Science in Espoo, Finland, for computing resources.

\section{REFERENCES}

(1) Ehn, M.; Thornton, J. A.; Kleist, E.; Sipilä, M.; Junninen, H.; Pullinen, I.; Springer, M.; Rubach, F.; Tillmann, R.; Lee, B.; et al. A Large Source of Low-Volatility Secondary Organic Aerosol. Nature 2014, 506, 476-479.

(2) Mentel, T. F.; Springer, M.; Ehn, M.; Kleist, E.; Pullinen, I.; Kurtén, T.; Rissanen, M.; Wahner, A.; Wildt, J. Formation of Highly Oxidized Multifunctional Compounds: Autoxidation of Peroxy Radicals Formed in the Ozonolysis of Alkenes - Deduced from Structure-Product Relationships. Atmos. Chem. Phys. 2015, 15, 67456765.

(3) Berndt, T.; Richters, S.; Kaethner, R.; Voigtländer, J.; Stratmann, F.; Sipilä, M.; Kulmala, M.; Herrmann, H. Gas-Phase Ozonolysis of Cycloalkenes: Formation of Highly Oxidized $\mathrm{RO}_{2}$ Radicals and Their Reactions With $\mathrm{NO}, \mathrm{NO}_{2}, \mathrm{SO}_{2}$, and Other $\mathrm{RO}_{2}$ Radicals. J. Phys. Chem. A 2015, 119, 10336-10348.

(4) Rissanen, M. P.; Kurtén, T.; Sipilä, M.; Thornton, J. A.; Kangasluoma, J.; Sarnela, N.; Junninen, H.; Jørgensen, S.; Schallhart, S.; Kajos, M. K.; et al. The Formation of Highly Oxidized Multifunctional Products in the Ozonolysis of Cyclohexene. J. Am. Chem. Soc. 2014, 136, 15596-15606.

(5) Peeters, J.; Nguyen, T. L.; Vereecken, L. HO $\mathrm{H}_{x}$ Radical Regeneration in the Oxidation of Isoprene. Phys. Chem. Chem. Phys. 2009, 11, 5935-5939.

(6) Asatryan, R.; da Silva, G.; Bozzelli, J. W. Quantum Chemical Study of the Acrolein $\left(\mathrm{CH}_{2} \mathrm{CHCHO}\right)+\mathrm{OH}+\mathrm{O}_{2}$ Reactions. J. Phys. Chem. A 2010, 114, 8302-8311.

(7) Vereecken, L.; Peeters, J. Decomposition of Substituted Alkoxy Radicals - Part I: A Generalized Structure-Activity Relationship for Reaction Barrier Heights. Phys. Chem. Chem. Phys. 2009, 11, 90629074.

(8) Archibald, A. T.; Petit, A. S.; Percival, C. J.; Harvey, J. N.; Shallcross, D. E. On the Importance of the Reaction Between $\mathrm{OH}$ and $\mathrm{RO}_{2}$ Radicals. Atmos. Sci. Lett. 2009, 10, 102-108.

(9) Fittschen, C.; Whalley, L. K.; Heard, D. E. The Reaction of $\mathrm{CH}_{3} \mathrm{O}_{2}$ Radicals with $\mathrm{OH}$ Radicals: A Neglected Sink for $\mathrm{CH}_{3} \mathrm{O}_{2}$ in the Remote Atmosphere. Environ. Sci. Technol. 2014, 48, 7700-7701.

(10) Bossolasco, A.; Faragó, E. P.; Schoemaecker, C.; Fittschen, C. Rate Constant of the Reaction Between $\mathrm{CH}_{3} \mathrm{O}_{2}$ Radicals and $\mathrm{OH}$ Radicals. Chem. Phys. Lett. 2014, 593, 7-13.

(11) Assaf, E.; Song, B.; Tomas, A.; Schoemaecker, C.; Fittschen, C. Rate Constant of the Reaction Between $\mathrm{CH}_{3} \mathrm{O}_{2}$ Radicals and $\mathrm{OH}$ Radicals Revisited. J. Phys. Chem. A 2016, 120, 8923-8932.

(12) Yan, C.; Kocevska, S.; Krasnoperov, L. N. Kinetics of the Reaction of $\mathrm{CH}_{3} \mathrm{O}_{2}$ Radicals with $\mathrm{OH}$ Studied Over the 292-526 K Temperature Range. J. Phys. Chem. A 2016, 120, 6111-6121.

(13) Müller, J.-F.; Liu, Z.; Nguyen, V. S.; Stavrakou, T.; Harvey, J. N.; Peeters, J. The Reaction of Methyl Peroxy and Hydroxyl Radicals as a Major Source of Atmospheric Methanol. Nat. Commun. 2016, 7, 13213.

(14) Bian, H.; Zhang, S.; Zhang, H. Theoretical Study on the Atmospheric Reaction of $\mathrm{CH}_{3} \mathrm{O}_{2}$ with OH. Int. J. Quantum Chem. 2015, $115,1181-1186$.

(15) Liu, Y.; Chen, L.; Chen, D.; Wang, W.; Liu, F.; Wang, W. Computational Study on Mechanisms of $\mathrm{C}_{2} \mathrm{H}_{5} \mathrm{O} 2+\mathrm{OH}$ Reaction and Properties of $\mathrm{C}_{2} \mathrm{H}_{5} \mathrm{O}_{3} \mathrm{H}$ complex. Chem. Res. Chin. Univ. 2017, 33, 623-630.

(16) Caravan, R. L.; Khan, M. A. H.; Zádor, J.; Sheps, L.; Antonov, I. O.; Rotavera, B.; Ramasesha, K.; Au, K.; Chen, M.-W.; Rösch, D.; et al. The Reaction of Hydroxyl and Methylperoxy Radicals is Not a Major Source of Atmospheric Methanol. Nat. Commun. 2018, 9, 4343-4352.

(17) Assaf, E.; Tanaka, S.; Kajii, Y.; Schoemaecker, C.; Fittschen, C. Rate Constants of the Reaction of $\mathrm{C}_{2}-\mathrm{C}_{4}$ Peroxy Radicals with $\mathrm{OH}$ Radicals. Chem. Phys. Lett. 2017, 684, 245-249.

(18) Assaf, E.; Sheps, L.; Whalley, L.; Heard, D.; Tomas, A.; Schoemaecker, C.; Fittschen, C. The Reaction Between $\mathrm{CH}_{3} \mathrm{O}_{2}$ and $\mathrm{OH}$ Radicals. Product Yields and Atmospheric Implications. Environ. Sci. Technol. 2017, 51, 2170-2177.

(19) Assaf, E.; Schoemaecker, C.; Vereecken, L.; Fittschen, C. Experimental and Theoretical Investigation of the Reaction of $\mathrm{RO}_{2}$ 
Radicals with OH Radicals: Dependence of the $\mathrm{HO}_{2}$ Yield on the Size of the Alkyl Group. Int. J. Chem. Kinet. 2018, 50, 670-680.

(20) Hasson, A. S.; Kuwata, K. T.; Arroyo, M. C.; Petersen, E. B. Theoretical Studies of the Reaction of Hydroperoxy Radicals $\left(\mathrm{HO}_{2}\right)$ With Ethyl Peroxy $\left(\mathrm{CH}_{3} \mathrm{CH}_{2} \mathrm{O}_{2}\right)$, Acetyl Peroxy $\left(\mathrm{CH}_{3} \mathrm{C}(\mathrm{O}) \mathrm{O}_{2}\right)$, and Acetonyl Peroxy $\left(\mathrm{CH}_{3} \mathrm{C}(\mathrm{O}) \mathrm{CH}_{2} \mathrm{O}_{2}\right)$ Radicals. J. Photochem. Photobiol., A 2005, 176, 218-230.

(21) Mohr, C.; Lopez-Hilfiker, F. D.; Yli-Juuti, T.; Heitto, A.; Lutz, A.; Hallquist, M.; D'Ambro, E. L.; Rissanen, M. P.; Hao, L.; Schobesberger, S.; et al. Ambient Observations of Dimers From Terpene Oxidation in the Gas-Phase: Implications For New Particle Formation and Growth. Geophys. Res. Lett. 2017, 44, 2958-2966.

(22) Tröstl, J.; Chuang, W. K.; Gordon, H.; Heinritzi, M.; Yan, C.; Molteni, U.; Ahlm, L.; Frege, C.; Bianchi, F.; Wagner, R.; et al. The Role of Low-Volatility Organic Compounds in Initial Particle Growth in the Atmosphere. Nature 2016, 533, 527-531.

(23) Kahnt, A.; Vermeylen, R.; Iinuma, Y.; Safi Shalamzari, M.; Maenhaut, W.; Claeys, M. High-Molecular-Weight Esters in $\alpha$-Pinene Ozonolysis Secondary Organic Aerosol: Structural Characterization and Mechanistic Proposal for their Formation from Highly Oxygenated Molecules. Atmos. Chem. Phys. 2018, 18, 8453-8467.

(24) Rissanen, M. P.; Kurtén, T.; Sipilä, M.; Thornton, J. A.; Kausiala, O.; Garmash, O.; Kjaergaard, H. G.; Petäjä, T.; Worsnop, D. R.; Ehn, M.; et al. Effects of Chemical Complexity on the Autoxidation Mechanisms of Endocyclic Alkene Ozonolysis Products: From Methylcyclohexenes Toward Understanding $\alpha$-Pinene. J. Phys. Chem. A 2015, 119, 4633-4650.

(25) Ehn, M.; Kleist, E.; Junninen, H.; Petäjä, T.; Lönn, G.; Schobesberger, S.; Dal Maso, M.; Trimborn, A.; Kulmala, M.; Worsnop, D. R.; et al. Gas Phase Formation of Extremely Oxidized Pinene Reaction Products in Chamber and Ambient Air. Atmos. Chem. Phys. 2012, 12, 5113-5127.

(26) Krapf, M.; El Haddad, I.; Bruns, E. A.; Molteni, U.; Daellenbach, K. R.; Prévôt, A. S.; Baltensperger, U.; Dommen, J. Labile Peroxides in Secondary Organic Aerosol. Chem. 2016, 1, 603-616.

(27) Zhao, J.; Ortega, J.; Chen, M.; McMurry, P. H.; Smith, J. N. Dependence of Particle Nucleation and Growth on High-MolecularWeight Gas-Phase Products During Ozonolysis of $\alpha$-Pinene. Atmos. Chem. Phys. 2013, 13, 7631-7644.

(28) Long, B.; Bao, J. L.; Truhlar, D. G. Atmospheric Chemistry of Criegee Intermediates: Unimolecular Reactions and Reactions with Water. J. Am. Chem. Soc. 2016, 138, 14409-14422.

(29) Johnson, D.; Marston, G. The Gas-Phase Ozonolysis of Unsaturated Volatile Organic Compounds in the Troposphere. Chem. Soc. Rev. 2008, 37, 699-716.

(30) Vereecken, L. Lifting the Veil on an Old Mystery. Science 2013, 340, 154-155.

(31) Taatjes, C. A.; Shallcross, D. E.; Percival, C. Research Frontiers in the Chemistry of Criegee Intermediates and Tropospheric Ozonolysis. Phys. Chem. Chem. Phys. 2014, 16, 1704-1718.

(32) Russell, G. A. Deuterium-Isotope Effects in the Autoxidation of Aralkyl Hydrocarbons. Mechanism of the Interaction of Peroxy Radicals. J. Am. Chem. Soc. 1957, 79, 3871-3877.

(33) Howard, J. A.; Ingold, K. U. Self-Reaction of Sec-Butylperoxy Radicals. Confirmation of the Russell Mechanism. J. Am. Chem. Soc. 1968, 90, 1056-1058.

(34) Halgren, T. A. Merck Molecular Force Field. I. Basis, Form, Scope, Parameterization, and Performance of MMFF94. J. Comput. Chem. 1996, 17, 490-519.

(35) Halgren, T. A. Merck Molecular Force Field. II. MMFF94 Van Der Waals and Electrostatic Parameters for Intermolecular Interactions. J. Comput. Chem. 1996, 17, 520-552.

(36) Halgren, T. A. Merck Molecular Force Field. III. Molecular Geometries and Vibrational Frequencies for MMFF94. J. Comput. Chem. 1996, 17, 553-586.

(37) Halgren, T. A.; Nachbar, R. B. Merck Molecular Force Field. IV. Conformational Energies and Geometries for MMFF94. J. Comput. Chem. 1996, 17, 587-615.
(38) Halgren, T. A. Merck Molecular Force Field. V. Extension of MMFF94 Using Experimental Data, Additional Computational Data, and Empirical Rules. J. Comput. Chem. 1996, 17, 616-641.

(39) Halgren, T. A. MMFF VII. Characterization of MMFF94, MMFF94s, and Other Widely Available Force Fields for Conformational Energies and for Intermolecular-Interaction Energies and Geometries. J. Comput. Chem. 1999, 20, 730-748.

(40) Spartan '14; Wavefunction Inc.: Irvine, CA, 2014.

(41) Chai, J. D.; Head-Gordon, M. Long-Range Corrected Hybrid Density Functionals with Damped Atom-Atom Dispersion Corrections. Phys. Chem. Chem. Phys. 2008, 10, 6615-6620.

(42) Dunning, T. H. Gaussian Basis Sets for Use in Correlated Molecular Calculations. I. The Atoms Boron Through Neon and Hydrogen. J. Chem. Phys. 1989, 90, 1007-1023.

(43) Kendall, R. A.; Dunning, T. H.; Harrison, R. J. Electron Affinities of the First-Row Atoms Revisited. Systematic Basis Sets and Wave Functions. J. Chem. Phys. 1992, 96, 6796-6806.

(44) Becke, A. D. Density-Functional Thermochemistry. III. The Role of Exact Exchange. J. Chem. Phys. 1993, 98, 5648-5652.

(45) Lee, C.; Yang, W.; Parr, R. H. Development of the Colle-Salvetti Correlation-Energy Formula Into a Functional of the Electron Density. Phys. Rev. B: Condens. Matter Mater. Phys. 1988, 37, 785-789.

(46) Hehre, W. J.; Ditchfield, R.; Pople, J. A. Self-Consistent Molecular Orbital Methods. XII. Further Extensions of Gaussian-Type Basis Sets for Use in Molecular Orbital Studies of Organic Molecules. J. Chem. Phys. 1972, 56, 2257-2261.

(47) Clark, T.; Chandrasekhar, J.; Spitznagel, G. W.; Schleyer, P. v. R. Efficient Diffuse Function-Augmented Basis Sets for Anion Calculations. III. The 3-21+G Basis Set for First-Row Elements, Li-F. J. Comput. Chem. 1983, 4, 294-301.

(48) Frisch, M. J.; Pople, J. A.; Binkley, J. S. Self-Consistent Molecular Orbital Methods 25. Supplementary Functions for Gaussian Basis Sets. J. Chem. Phys. 1984, 80, 3265-3269.

(49) Werner, H.-J.; Knowles, P. J.; Knizia, G.; Manby, F. R.; Schütz, M.; Celani, P.; Korona, T.; Lindt, R.; Mitrushenkov, A.; Rauhut, G.; et al. MOLPRO, version 2015.1, A Package of Ab Initio Programs; 2015; see http://www.molpro.net (Retrieved Apr 1, 2019).

(50) Glowacki, D. R.; Liang, C.-H.; Morley, C.; Pilling, M. J.; Robertson, S. H. MESMER: Open-Source Master Equation Solver for Multi-Energy Well Reactions. J. Phys. Chem. A 2012, 116, 9545-9560.

(51) Bartis, J. T.; Widom, B. Stochastic Models of the Interconversion of Three or More Chemical Species. J. Chem. Phys. 1974, 60, 34743482.

(52) Carr, S. A.; Still, T. J.; Blitz, M. A.; Eskola, A. J.; Pilling, M. J.; Seakins, P. W.; Shannon, R. J.; Wang, B.; Robertson, S. H. Experimental and Theoretical Study of the Kinetics and Mechanism of the Reaction of OH Radicals with Dimethyl Ether. J. Phys. Chem. A 2013, 117, $11142-11154$.

(53) Carr, S. A.; Glowacki, D. R.; Liang, C. H.; Baeza-Romero, M. T.; Blitz, M. A.; Pilling, M. J.; Seakins, P. W. Experimental and Modeling Studies of the Pressure and Temperature Dependences of the Kinetics and the $\mathrm{OH}$ Yields in the Acetyl $+\mathrm{O}_{2}$ Reaction. J. Phys. Chem. A 2011, $115,1069-1085$.

(54) Shannon, R. J.; Tomlin, A. S.; Robertson, S. H.; Blitz, M. A.; Pilling, M. J.; Seakins, P. W. Global Uncertainty Propagation and Sensitivity Analysis in the $\mathrm{CH}_{3} \mathrm{OCH}_{2}+\mathrm{O}_{2}$ System: Combining Experiment and Theory To Constrain Key Rate Coefficients in DME Combustion. J. Phys. Chem. A 2015, 119, 7430-7438.

(55) Stone, D.; Au, K.; Sime, S.; Medeiros, D. J.; Blitz, M.; Seakins, P. W.; Decker, Z.; Sheps, L. Unimolecular Decomposition Kinetics of the Stabilized Criegee Intermediates $\mathrm{CH}_{2} \mathrm{OO}$ and $\mathrm{CD}_{2} \mathrm{OO}$. Phys. Chem. Chem. Phys. 2018, 20, 24940-24954. 